\title{
FAKTOR-FAKTOR YANG MEMPENGARUHI TINGKAT KEUNTUNGAN DAN EFISIENSI PADA USAHA RAKYAT PERKEBUNAN KELAPA
}

\author{
Bedy Sudjarmoko \\ Balai Penelitian Tanaman Rempah dan Aneka Tanaman Industri \\ Jl. Raya Pakuwon Km. 2 Parungkuda, Sukabumi 43357 \\ E-mail : bedy_sm@yahoo.com atau balittri@gmail.com
}

\begin{abstract}
ABSTRAK. Kelapa merupakan salahsatu komoditas perkebunan yang penting di Indonesia, baik dari aspek ekonomi maupun dari aspek sosial dan budayanya. Berdasarkan data tahun 2004, 97\% usaha perkebunan kelapa dilakukan oleh petani rakyat. Maka di dalam konteks pembangunan pertanian, berbagai informasi mengenai faktor-faktor yang dapat mempengaruhi keuntungan dari usaha perkebunan tersebut merupakan simpul penting dalam upaya-upaya peningkatan produksi secara lebih efektif. Penelitian ini bertujuan untuk; (1) mengidentifikasi faktor-faktor yang dapat mempengaruhi tingkat keuntungan usaha perkebunan kelapa; dan (2) menentukan tingkat efisiensi produksi pada perkebunan kelapa yang diusahakan oleh petani kecil. Model Unit Output Price Cobb-Douglass Profit Function digunakan untuk menggambarkan hubungan antara tingkat keuntungan dengan faktor-faktor tersebut. Model tersebut kemudian dianalisis dengan menggunakan prosedur Seemingly Unrelated Regression (SUR) untuk menghasilkan parameter model. Hasil analisis menunjukkan bahwa tingkat upah, harga pupuk dan pestisida, memberikan dampak yang signifikan secara negatif terhadap tingkat keuntungan. Lebih jauh, seluruh input tetap dan faktor demografis memberikan dampak signifikan postitif terhadap tingkat keuntungan tersebut. Selain itu, model analisis juga menunjukkan bahwa usaha perkebunan rakyat berada pada kondisi increasing return to scale, yang berarti bahwa keuntungan usaha perkebunan masih dapat ditingkatkan dengan menambah jumlah tenaga kerja, pupuk dan pestisida sampai pada titik optimum.
\end{abstract}

Kata kunci: cocos nucifera, fungsi keuntungan, return to scale, efisiensi.

\section{FACTORS INFLUENCING PROFIT AND EFFICIENCY IN A SMALLHOLDER COCONUT ESTATE}

ABSTRACT. The coconut is very important comodity in Indonesia, not only from the economic point of view, but also its social and culture value. According to data compiled in 2004, for about $97 \%$ of the 3,7 million hectares coconut plantation was occupied by smallholder, with 0,5 hectare land per family on average. In the context of agriculture development, any information about factors, such as demographic, return to scale and efficiency, are very critical for government to intensify its efforts in order to improve coconut production in a sound of more effectively way. This study has two main objective: (1) to identify factors that 
affecting the profit of coconut farming; and (2) to identify the level of its relative efficiency. The Unit Output Price Cobb-Douglass Profit Function is utilized to model smallholder coconut farming, and Seemingly Unrelated Regression (SUR) procedure to estimate parameters. The model revealed that labour wage, price of fertilizers (Urea, SP-36, $\mathrm{KCl}$ ) and pesticides, gave significant negative effect to the level of profit of coconut farming. Except the farmer educational level, all of the fixed inputs and demographic factors (number of coconut, coconut's age and farmer's experience) inversly have positive effect. This study also confirmed that coconut farming was indeed on the stage of increasing return to scale. Hence, profit would increase by further utilization of labour, Urea, SP-36, $\mathrm{KCl}$ and pesticides, until the optimum limit reached.

Key words: Cocos nucifera, profit function, return to scale, efficiency.

\section{PENDAHULUAN}

Peranan kelapa sebagai komoditi perkebuan bagi masyarakat Indonesia dan negara sangat besar. Setidaknya ada enam peranan kelapa dalam perekonomian nasional, yaitu: (1) sebagai sumber utama minyak nabati dalam negeri, (2) sebagai komoditas ekspor dan sumber devisa negara, (3) sebagai sumber pendapatan petani, (4) sebagai sumber bahan baku industri dalam negeri, (5) sebagai sumber penyedia lapangan kerja bagi masayarakat, dan (6) sebagai salah satu unsur pelestari lingkungan hidup. Komoditi kelapa nasional pada periode $1960-1970$ pernah mengalami masa kejayaan dengan produk utama kopra, sedangkan kopra sendiri pada waktu itu menjadi produk yang menguntungkan untuk diusahakan. Namun dalam perkembangannya terutama pada dekade 1980-1990, peranan kelapa sebagai sumber bahan baku minyak goreng makin tergeser peranannya oleh kelapa sawit. Berdasarkan luasnya, Indonesia merupakan negara dengan areal pertanaman kelapa terluas di dunia, dengan luas mencapai 3.7 juta hektar, atau dengan pangsa areal sebesar $31.2 \%$ dari total dunia. Namun berdasarkan produksi minyak kelapa, sebagai produk utama dari perkebunan kelapa, Indonesia hanya berada pada posisi kedua dunia (dengan pangsa sebesar $25.5 \%$ dari total dunia), sementara Filipina, sebagai negara produsen minyak kelapa terbesar, mampu menguasai pangsa produksi sebesar lebih dari $41 \%$.

Masalah utama yang dihadapi oleh perkebunan kelapa yang diusahakan oleh petani kecil adalah: (1) rendahnya produktivitas tanaman, (2) sempitnya lahan usahatani, (3) rendah dan fluktuatifnya harga produk primer kelapa yang dihasilkan di tingkat petani, dan (4) turunnya nilai tukar komoditas kelapa terhadap kebutuhan primer petani. Disamping itu, banyaknya tanaman kelapa berumur tua, pola usahatani yang monokultur, inkonsistensi dalam diversifikasi produk serta lambatnya proses adopsi teknologi juga merupakan faktor yang sangat mempengaruhi produktivitas perkebunan tersebut (Allorerung \& Mahmud, 2003; Tarigans, 2003; Tarigans \& Sumanto, 2004; Allorerung \& Tarigans, 2003). Sejalan dengan permasalahan tersebut, upaya pemerintah untuk meningkatkan 
produktivitas pertanaman kelapa dilakukan melalui intensifikasi dan rehabilitasi usaha perkebunan. Namun begitu, sesuatu yang tetap menjadi permasalahan di dalam upaya-upaya intensifikasi tersebut adalah kemampuan petani kelapa di Indonesia untuk melakukan alokasi sumberdaya yang sangat terbatas untuk mencapai tingkat efisiensi relatif di dalam usaha perkebunannya.

Tulisan ini secara umum memiliki tujuan untuk mengetahui efisiensi relatif dari perkebunan kelapa yang diusahakan oleh petani kecil. Sedangkan tujuan khusus dari penelitian ini adalah: (1) mengidentifikasi faktor-faktor yang mempengaruhi keuntungan; dan (2) menganalisis tingkat efsisiensi relatif usaha perkebunan kelapa. Penelitian ini diharapkan dapat menjadi bahan pertimbangan dan masukan bagi pengembangan komoditas kelapa di Indonesia pada masa yang akan datang, khususnya yang dikelola dalam bentuk perkebunan rakyat.

\section{METODE PENELITIAN}

Penelitian ini telah dilaksanakan pada bulan Januari 2002 - Desember 2006 di Kabupaten Inderagiri Hilir, Riau dan Kabupaten Bulukumba, Sulawesi Selatan dengan metoda survei. Pemilihan lokasi penelitian dilakukan dengan sengaja (purposive) dengan pertimbangan bahwa program intensifikasi perkebunan kelapa dilaksanakan di kedua wilayah tersebut. Desa yang terpilih di Kab. Inderagiri Hilir adalah Desa Belaras dan Igal di Kecamatan Mandah, serta Desa Sei Ara dan Tempuling di Kecamatan Tempuling, sementara di Kab. Bulukumba adalah Desa Perangian dan Bontongan di Kecamatan Ujung Bulu serta desa Kadingeh dan Tirowali di Kecamatan Bontobahari. Petani yang dijadikan petani contoh adalah sebanyak 260 orang, dipilih secara acak (simple random sampling) proporsional dengan jumlah total petani di wilayah desa, masing-masing 138 orang di Kab. Inderagiri Hilir dan 122 orang di Kabupaten Bulukumba. Penelitian ini menggunakan data primer yang bersifat kerat lintang (cross section), serta ditunjang oleh data sekunder yang dikumpulkan melalui Direktorat Jenderal Perkebunan, Badan Pusat Statistik Indonesia, Asian and Pasific Coconut Community (APCC), Food and Agricultural Organization (FAO) dan sumber lain yang relevan dengan tujuan penelitian.

Identifikasi faktor-faktor yang mempengaruhi tingkat keuntungan pada perkebunanan kelapa dilakukan melalui pendugaan parameter pada fungsi keuntungan Unit Output Price Cobb-Douglas. Fungsi ini dibangun dari 11 peubah yang terdiri dari 5 input variabel, 4 input tetap dan 2 peubah boneka (dummy). Bentuk matematis dari fungsi keuntungan tersebut dapat dituliskan sebagai berikut:

$L_{n} \Pi^{*}=L_{n} A+\alpha_{1} L_{n} \sum_{n=1}^{5} W^{*}+\beta_{1} L_{n} \sum_{n=1}^{4} Z+\delta_{1} \sum_{1}^{2} D+\mu$

Dimana: $\Pi^{*}=$ keuntungan usahatani kelapa yang dinormalkan dengan harga output (Rp). $\mathrm{W}_{1}{ }^{*}=$ upah normal tenaga kerja (Rp). $\mathrm{W}_{2}{ }^{*}=$ harga normal pupuk urea (Rp). $\mathrm{W}_{3}{ }^{*}=$ harga normal pupuk SP-36 (Rp). $\mathrm{W}_{4}{ }^{*}=$ harga normal pupuk $\mathrm{KCl}$ 
(Rp). $\mathrm{W}_{5}{ }^{*}=$ harga normal pestisida (Rp). $\mathrm{Z1}=$ jumlah pohon kelapa (buah). $\mathrm{Z2}=$ umur pohon kelapa (tahun). Z3 = pengalaman usahatani petani (tahun). Z4 = tingkat pendidikan petani (tahun). $\mu=$ disturbance error. $\mathrm{a}_{i}^{*}=$ parameter dugaan input variabel $(i=1,2, . ., 5) \cdot \beta_{j}^{*}=$ parameter dugaan input tetap $(j=1,2, . .4) . \delta_{E}=$ parameter dummy, $\left(D_{E}=1\right.$ untuk ekosistem kelapa di wilayah pasang surut; $D_{E}=$ 0 untuk ekosistem kelapa lahan kering). $\delta_{\mathrm{L}}=$ parameter dummy, $\left(D_{\mathrm{L}}=1\right.$ untuk usahatani kelapa dengan luas lahan $\leq 0.50 \mathrm{Ha} ; \mathrm{D}_{L_{*}}=0$ untuk lahan yang $>0.50$ $\mathrm{Ha}$ ). Tanda parameter dugaan yang diharapkan: $\mathrm{a}_{1}{ }^{*}, \mathrm{a}_{2}{ }^{*}, \mathrm{a}_{3}{ }^{*}, \mathrm{a}_{4}{ }^{*}, \mathrm{a}_{5}{ }^{*}<0 ; \beta_{1}{ }^{*}, \beta_{2}{ }^{*}, \beta_{3}{ }^{*}$, $\beta_{4}{ }^{*}>0 ; \delta_{\mathrm{E}}, \delta_{\mathrm{L}}>0$. Selanjutnya, persamaan (1) dapat diderivasikan menjadi persamaan pangsa input (factor share); yang menunjukkan besarnya sumbangan atau kontribusi input variabel terhadap keuntungan. Bentuk fungsi tersebut dapat dituliskan secara matematis seperti berikut ini:

$$
\frac{x_{1} w_{1}^{*}}{\Pi}=-\frac{\delta L n \Pi^{*}}{\delta L n w^{*}} \text { atau; } S_{i}=-\left(\alpha_{i}+\mu\right) ;(\mathrm{i}=1,2, . ., 5)
$$

Dimana Siadalah pangsa masing-masing input di dalam usahatani kelapa.

Dengan menggunakan persamaan (2), maka pengujian keuntungan maksimum dilakukan dengan kaidah:

$$
H_{0}: \alpha_{i}=\alpha_{j}=0 \text { dan } H_{a}: \alpha_{i}=\alpha_{j} \neq 0 ; \mathrm{i}=(1,2, \ldots ., 5), \mathrm{j}=(2,3, . ., 5) \text {. }
$$

Pengujian skala usahatani kelapa dilakukan dengan kaidah:

$$
H_{0}: \sum_{1}^{4} \beta_{i}=1 \text { dan } H_{a}: \sum_{1}^{4} \beta_{i}>1 ; \mathrm{i}=(1,2, . ., 4) \text {. }
$$

Untuk mendapatkan fungsi yang dapat dijelaskan dengan baik (best fit) oleh data yang digunakan, maka pendugaan parameter pada fungsi keuntungan dilakukan dengan metode ordinary least square (OLS) dan seemingly unrelated regression (SUR) secara simultan dengan fungsi factor share. Metode tersebut diterapkan kepada tiga model penduga; model I adalah fungsi keuntungan standar (dengan metode OLS), model II (dengan SUR tanpa restriksi kehomogenan') dan model III (pendugaan dengan metode SUR dengan restriksi). Hal ini dimaksudkan untuk mendapatkan parameter-parameter dugaan yang efisien (Intrilligator, et al, 1996; Lau and Yotopaulus, 1972; Garcia, et al, 1982). Pengolahan data dilakukan dengan menggunakan program Statistical Analysis System (SAS) versi 9.

\section{HASIL PENDUGAAN PARAMETER PADA FUNGSI KEUNTUNGAN}

Dari tiga model penduga parameter yang digunakan, model III (SUR pada kondisi optimum) ternyata memberikan parameter dugaan yang efisien. Sedangkan model I, parameter yang dihasilkan terlihat tidak konsisten. Hal ini dapat dilihat dari 
Faktor-Faktor yang Mempengaruhi Tingkat Keuntungan dan Efisiensi pada Usaha Rakyat Perkebunan Kelapa (Bedy Sudjarmoko)

kesalahan penaksiran standar (standard error) dan besaran serta tanda parameter (Tabel 1).

Tabel 1. Pendugaan parameter pada fungsi keuntungan.

\begin{tabular}{|c|c|c|c|c|}
\hline \multirow{2}{*}{ Peubah } & \multirow{2}{*}{ Parameter } & \multicolumn{3}{|c|}{ Nilai Parameter } \\
\hline & & $\mathrm{I}$ & II & III \\
\hline Konstanta & $A *$ & $\begin{array}{c}18.2935 * * * \\
(0.2601)\end{array}$ & $\begin{array}{c}17.3108 * * * \\
(0.2114)\end{array}$ & $\begin{array}{c}21.2754 * * * \\
(0.1027)\end{array}$ \\
\hline Tenaga Kerja & $a_{1}^{*}$ & $\begin{array}{c}-1.2662 * * \\
(0.0196)\end{array}$ & $\begin{array}{c}-0.0201 * \\
(0.0115)\end{array}$ & $\begin{array}{c}-0.0236 * * \\
(0.0043)\end{array}$ \\
\hline Pupuk Urea & $a_{2}{ }^{*}$ & $\begin{array}{c}0.2501 \\
(0.1302)\end{array}$ & $\begin{array}{c}-0.1404 * * \\
(0.0124)\end{array}$ & $\begin{array}{c}-0.0454 * * \\
(0.0016)\end{array}$ \\
\hline Pupuk SP-36 & $a_{3}{ }^{*}$ & $\begin{array}{l}-0.3724 \\
(0.0731)\end{array}$ & $\begin{array}{c}-0.2508 * * * \\
(0.0157)\end{array}$ & $\begin{array}{c}-0.1862 * * * \\
(0.0019)\end{array}$ \\
\hline Pupuk KCl & $a_{4}{ }^{*}$ & $\begin{array}{l}0.4566 * \\
(0.0811)\end{array}$ & $\begin{array}{c}-0.2033 * * * \\
(0.0323)\end{array}$ & $\begin{array}{c}-0.0575 * * * \\
(0.0144)\end{array}$ \\
\hline Pestisida & $a_{5}{ }^{*}$ & $\begin{array}{l}-0.3771 \\
(0.0623)\end{array}$ & $\begin{array}{c}-0.2364 * * * \\
(0.0427)\end{array}$ & $\begin{array}{c}-0.2482 * * * \\
(0.0326)\end{array}$ \\
\hline Jumlah pohon kelapa & $\beta_{1} *$ & $\begin{array}{c}0.8458 * * * \\
(0.1018)\end{array}$ & $\begin{array}{c}0.5612 * * * \\
(0.0454)\end{array}$ & $\begin{array}{c}0.2753 * * * \\
(0.0251)\end{array}$ \\
\hline Umur pohon kelapa & $\beta_{2} *$ & $\begin{array}{c}0.6373 * * * \\
(0.1142)\end{array}$ & $\begin{array}{l}0.0888 * \\
(0.0522)\end{array}$ & $\begin{array}{c}0.2108 * * * \\
(0.0270)\end{array}$ \\
\hline Pengalaman usahatani & $\beta_{3} *$ & $\begin{array}{c}0.1234 \\
(0.0901)\end{array}$ & $\begin{array}{c}0.5990 * * * \\
(0.0651)\end{array}$ & $\begin{array}{c}0.4204 * * * \\
(0.0332)\end{array}$ \\
\hline Pendidikan petani & $\beta_{4} *$ & $\begin{array}{c}0.0027 \\
(0.1026)\end{array}$ & $\begin{array}{l}0.0847 * \\
(0.0603)\end{array}$ & $\begin{array}{c}0.0815 * * * \\
(0.0162)\end{array}$ \\
\hline Ekosistem Usahatani & $\delta D_{E}$ & $\begin{array}{l}-0.2854 \\
(0.0872)\end{array}$ & $\begin{array}{c}-0.3312 * * \\
(0.0577)\end{array}$ & $\begin{array}{c}-0.1424 * * * \\
(0.0214)\end{array}$ \\
\hline Luas lahan usahatani & $\delta_{L} L_{L}$ & $\begin{array}{c}-0.4177 * \\
(0.0943)\end{array}$ & $\begin{array}{c}-0.2780 * * \\
(0.0568) \\
\end{array}$ & $\begin{array}{c}-0.3672 * * * \\
(0.0237)\end{array}$ \\
\hline & $\begin{array}{c}\sum \beta_{j}{ }^{*} \\
R^{2} \\
\text { Adj } R^{2}\end{array}$ & $\begin{array}{l}1.6092 \\
0.8823 \\
0.8136 \\
\end{array}$ & $\begin{array}{l}1.3337 \\
0.9144 \\
0.8982 \\
\end{array}$ & $\begin{array}{l}0.9880 \\
0.9154 \\
0.8991 \\
\end{array}$ \\
\hline
\end{tabular}

Keterangan: (1) Model I = menggunakan metode pendugaan OLS. Model II = menggunakan metode pendugaan SUR (tanpa restriksi). Model III = menggunakan metode pendugaan SUR (dengan restriksi). (2) Tanda $(*)$ menunjukkan signifikansi pada tingkat kepercayaan $90 \%$ atau $a=10 \%$. Tanda $(* *)$ signifikan pada tingkat kepercayaan $95 \%$ atau $a=5 \%$. Tanda $(* * *)$ signifikan pada tingkat kepercayaan $99 \%$ atau $a=1 \%$. (3) Angka di dalam kurung (.) menunjukkan standard error.

Pendugaan parameter pada fungsi keuntungan memberikan nilai determinasi atau $\mathrm{R}^{2}$ antara 0.88 sampai 0.91 dan nyata pada taraf $1 \%$, ini berarti bahwa keragaman keuntungan petani kelapa $88 \%$ sampai $92 \%$ dapat dijelaskan oleh hubungannya dengan variabel bebas yang digunakan dalam model, sedangkan $8 \%$ sampai $12 \%$ dijelaskan oleh variabel lain di luar model. Atau dengan perkataan lain, peubah bebas yang digunakan dalam model penelitian dapat menerangkan variasi tingkat keuntungan perkebunan kelapa dengan baik karena hanya $8 \%$ sampai $12 \%$ dari variasi keuntungan usahatani kelapa ditentukan oleh peubah lain yang tidak disertakan di dalam model. 
Pada kondisi optimum, semua parameter dugaan input variabel mempunyai koefisien yang bertanda negatif dan memiliki pengaruh nyata secara statistik pada taraf uji $a=1 \%$ (pupuk SP-36, $\mathrm{KCl}$ dan pestisida) serta $\mathrm{a}=5 \%$ (tenaga kerja, pupuk Urea). Hal ini berarti bahwa harga-harga input variabel (tenaga kerja, pupuk Urea, SP-36, KCl dan pestisida) nyata memiliki hubungan negatif dengan tingkat keuntungan usahatani kelapa. Artinya, setiap meningkatnya upah tenaga kerja, harga pupuk Urea, SP-36, KCl dan pestisida, maka akan menurunkan tingkat keuntungan usahatani kelapa. Tanda dan besaran parameter dugaan input variabel tersebut mengindikasikan bahwa meningkatnya harga pestisida, pupuk SP-36, KCl, Urea dan tenaga kerja sebesar $10 \%$ akan menurunkan keuntungan usahatani kelapa masing-masing sebesar 25\%, 19\%,6\%, 5\% dan 2\%.

Perubahan harga pestisida dan pupuk $\mathrm{KCl}$ mempunyai pengaruh yang paling besar terhadap keuntungan usahatani kelapa. Dalam hal penggunaan pestisida, petani menyadari betul pentingnya penggunaan input ini terhadap output yang dihasilkan. Oleh karena harga pestisida relatif lebih mahal dibanding harga input lainnya, maka petani sedapat mungkin tidak mengabaikan faktor ini walaupun harus mensubstitusinya dengan penggunaan pestisida nabati. Perlindungan tanaman kelapa terhadap serangan hama dan penyakit dewasa ini lebih banyak didasarkan pada penanggulangan secara terpadu, sehingga penggunaan pestisida kimiawi bukan lagi menjadi satu-satunya alternatif cara penanggulangan. Teknik dan metode pengendalian hama serta penyakit tanaman kelapa dewasa ini lebih ditekankan pada penggunaan musuh alami dan organisme antagonis, seperti penggunaan Baculovirus, Metharizium sp. dan insekta predator lainnya, sehingga mampu menekan biaya penggunaan pestisida (Warokka et al., 2003).

Pada kondisi aktual, semua input variabel juga mempunyai tanda negatif yang mengindikasikan bahwa naiknya harga - harga input tersebut akan menurunkan tingkat keuntungan usahatani kelapa. Pengaruhnya terhadap penurunan tingkat keuntungan nyata secara statistik masing-masing pada taraf $a=1 \%$ untuk pestisida, pupuk $\mathrm{KCl}$ dan SP-36; $a=5 \%$ untuk pupuk Urea dan $a=10 \%$ untuk tenaga kerja. Tanda dan besaran parameter dugaan input variabel tersebut mengindikasikan bahwa meningkatnya harga pestisida, pupuk $\mathrm{KCl}$, SP-36, Urea dan tenaga kerja sebesar $10 \%$ akan menakibatkan turunnya keuntungan masingmasing sebesar $24 \%, 20 \%, 25 \%, 14 \%$ dan $2 \%$. Pada kondisi aktual, perubahan harga pestisida, pupuk KCl dan SP-36 mempunyai pengaruh paling besar terhadap keuntungan usahatani kelapa.

Dari lima input variabel yang diamati, dapat dilihat bahwa tenaga kerja mempunyai pengaruh yang paling kecil terhadap besarnya keuntungan pada usahatani kelapa. Hal ini disebabkan oleh banyaknya tenaga kerja yang berasal dari dalam keluarga pada usahatani kelapa rakyat. Sebagaimana umumnya petani di negara-negara berkembang lainnya, petani kelapa di Indonesia dihadapkan pada keterbatasan modal (Nair, 2003; Allorerung dan Mahmud, 2003, Mahmud, 1999). Hal ini juga sejalan dengan temuan beberapa peneliti lain (Saefudin, et al, 2002; Allorerung dan Mahmud, 2003), yang mengungkapkan bahwa secara umum 
perkebunan kelapa rakyat memang banyak menggunakan tenaga kerja dalam keluarga selain tenaga kerja luar keluarga yang diupah.

Menurunnya keuntungan usahatani yang diakibatkan oleh naiknya harga pestisida, pupuk dan tenaga kerja ini sejalan dengan hasil penelitian-penelitian lain yang telah dilaksanakan terdahulu. Saragih (1980) dalam penelitiannya tentang skala usaha pada perkebunan kelapa sawit di Sumatera Bagian Utara, juga menunjukkan adanya hubungan yang bersifat negatif antara harga-harga input dengan besarnya keuntungan kelapa sawit baik pada kebun yang dikelola oleh pemerintah maupun swasta asing. Input yang dimaksud adalah input variabel berupa harga pupuk, upah pegawai bulanan dan upah buruh harian dan buruh lepas. Begitu juga dengan penelitian yang dilakukan Santoso (1987) pada usahatani kopi rakyat di daerah Lampung. Hasilnya menunjukkan bahwa naiknya harga pupuk buatan, upah tenaga kerja pemeliharaan dan tenaga kerja panen akan menurunkan keuntungan pada usahatani kopi rakyat. Sementara Djaimi (2001) menunjukkan adanya hubungan negatif antara harga pupuk, upah tenaga kerja pria dan wanita dengan keuntungan kelapa sawit dan karet yang dikelola oleh perkebunan milik pemerintah. Hasil serupa juga masih ditemukan pada komoditas kelapa sawit (Susila, 1999), dan kelapa (Sudjarmoko, et al., 1999; Sudjarmoko, 2004)

Untuk input tetap (jumlah dan umur pohon kelapa, pengalaman usahatani dan pendidikan petani kelapa), semua mempunyai parameter dugaan bertanda positif yang mengindikasikan bahwa meningkatnya jumlah dan umur pohon kelapa, bertambahnya pengalaman usahatani dan pendidikan petani kelapa, akan meningkatkan keuntungan usahatani kelapa. Dalam jangka panjang, meningkatnya jumlah pohon kelapa, pengalaman usahatani petani, umur pohon kelapa dan pendidikan petani sebesar $10 \%$, akan meningkatkan keuntungan usahatani kelapa masing-masing sebesar $56 \%, 60 \%, 9 \%$ dan $8 \%$ (pada kondisi aktual) serta $28 \%$, $42 \%, 21 \%$ dan $8 \%$ (pada kondisi optimum). Semua input tetap berpengaruh nyata pada taraf $a=1 \%$ (pada kondisi optimum); $a=1 \%$ untuk jumlah pohon kelapa dan pengalaman usahatani, serta $a=10 \%$ untuk umur pohon kelapa dan pendidikan petani (pada kondisi aktual). Fenomena hubungan keuntungan dengan input variabel dan input tetap ini sesuai dengan teori ekonomi yang berlaku dan spesifikasi model yang digunakan.

Dari Tabel 1 juga diketahui bahwa kelapa pada ekosistem lahan pasang surut akan menerima keuntungan usahatani yang lebih kecil bila dibanding dengan usahatani kelapa pada lahan kering. Begitu juga dengan usahatani kelapa pada lahan sempit, keuntungan yang diperoleh lebih kecil bila dibanding dengan usahatani kelapa pada lahan luas. Hal ini dicerminkan oleh tanda dan besarnya nilai parameter untuk peubah boneka pada kedua kategori usahatani kelapa tersesebut. Pada kondisi aktual, nilai $\delta D_{E}=-0.3312$ dan $\delta D_{L}=-0.2780$ dan masing-masing nyata pada taraf $a=5 \%$. Sedangkan pada kondisi optimum nilai $\delta$ $D_{E}=-0.1424$ dan $\delta D_{L}=-0.3672$ dan masing-masing nyata pada taraf $a=1 \%$. 
Lebih kecilnya keuntungan usahatani kelapa di lahan pasang surut disebabkan oleh lebih tingginya biaya usahatani di ekosistem tersebut, baik karena kondisi infrastruktur maupun karena masalah teknis agronomis. Infrastruktur merupakan faktor penting dalam menunjang mobilitas arus barang dan jasa. Alat transportasi utama di wilayah pasang surut adalah laut dan sungai. Kondisi ini menyebabkan harga transportasi menjadi lebih mahal, sehingga tidak saja membebani petani dalam menjual hasil produksinya, tetapi juga dalam membeli sarana produksi dan input usahatani lainnya. Sementara itu, pengelolaan kelapa di lahan pasang surut membutuhkan pengolahan lahan dan pemeliharaan parit atau saluran air yang lebih intensif agar tidak meracuni tanaman kelapa (Allorerung, 1992; Herman, et al, 1998). Sedangkan lebih kecilnya keuntungan usahatani kelapa di lahan sempit, merupakan fenomena umum yang banyak dijumpai pada perkebunan rakyat. Kecenderungan secara umum memperlihatkan bahwa pendapatan petani akan meningkat seiring dengan makin luasnya lahan usahatani yang dikelola. Hal ini berhubungan erat dengan makin kecilnya biaya rata-rata yang harus dikeluarkan oleh petani berlahan luas, sejalan dengan hasil penelitian - penelitian lain yang pernah dilakukan terdahulu (Sondakh, 1993; Tarigans dan Sumanto, 2002).

\section{HASIL PENDUGAAN PARAMETER PADA PERSAMAAN FACTOR SHARE}

Factor share merupakan besarnya sumbangan atau kontribusi suatu input variabel terhadap besarnya keuntungan usahatani kelapa. Hasil dugaan parameter fungsi factor share dari usahatani kelapa yang dianalisis dapat dilihat pada Tabel 2. Pada kondisi aktual, kontribusi seluruh input variabel terhadap besarnya keuntungan usahatani kelapa adalah sebesar $59 \%$, dan $41 \%$ berasal dari kontribusi input tetap. Dari $59 \%$ kontribusi input variabel tersebut, masing-masing berasal dari tenaga kerja 3\%, pupuk Urea sebesar 6\%, pupuk SP-36 sebesar $21 \%$, pupuk $\mathrm{KCl}$ sebesar $7 \%$ dan pestisida sebesar $22 \%$. Berdasarkan konfigurasi kontribusi tiaptiap input variabel tersebut, dapat dilihat bahwa pada kondisi aktual, kontribusi terbesar disumbangkan oleh pestisida dan pupuk SP-36, kemudian berturut-turut diikuti oleh pupuk $\mathrm{KCl}$, Urea dan tenaga kerja. Ini berarti bahwa upaya untuk meningkatkan keuntungan usahatani kelapa sangat dipengaruhi oleh berhasil tidaknya petani menekan biaya penggunaan pestisida dan pupuk SP-36.

Sedangkan pada kondisi optimum, kontribusi seluruh input variabel tersebut hanya $56 \%$ dan sisanya sebesar $44 \%$ disumbangkan oleh input tetap. Dari $56 \%$ kontribusi input variabel tersebut, masing-masing berasal dari tenaga kerja $2 \%$, pupuk Urea 5\%, pupuk SP-36 19\%, pupuk $\mathrm{KCl} 6 \%$ dan pestisida sebesar $25 \%$. Pada kondisi optimum, kontribusi terbesar juga disumbangkan oleh pestisida dan pupuk SP-36 kemudian berturut-turut diikuti oleh pupuk $\mathrm{KCl}$, Urea dan tenaga kerja. Sama halnya seperti pada kondisi aktual, upaya untuk meningkatkan keuntungan usahatani kelapa sangat dipengaruhi oleh berhasil tidaknya petani menekan biaya penggunaan pestisida dan pupuk SP-36. Hal ini mengindikasikan bahwa keuntungan usahatani kelapa akan semakin tinggi bila biaya-biaya untuk penggunaan input pestisida dan pupuk SP-36 dapat ditekan serendah mungkin. 
Tabel 2. Pendugaan parameter pada persamaan factor share.

\begin{tabular}{|c|c|c|c|c|}
\hline \multirow{2}{*}{ Peubah } & \multirow{2}{*}{ Parameter } & \multicolumn{3}{|c|}{ Nilai Parameter } \\
\hline & & $\mathrm{I}$ & II & III \\
\hline 1. Tenaga Kerja & $a_{1}{ }^{\prime \prime}$ & $\begin{array}{c}-0.0427 * \\
(0.0020)\end{array}$ & $\begin{array}{r}-0.0322 \\
(0.0014)\end{array}$ & $\begin{array}{c}-0.0236 * * * \\
(0.0011)\end{array}$ \\
\hline 2. Pupuk Urea & $a_{2}{ }^{\prime \prime}$ & $\begin{array}{l}-0.0812 \\
(0.0023)\end{array}$ & $\begin{array}{c}-0.0609 * \\
(0.0018)\end{array}$ & $\begin{aligned}- & 0.0454 * * * \\
& (0.0014)\end{aligned}$ \\
\hline 3. Pupuk SP-36 & $a_{3}{ }^{* \prime}$ & $\begin{aligned}- & 0.2717 * * \\
& (0.0025)\end{aligned}$ & $\begin{array}{c}-0.2104 * * * \\
(0.0014)\end{array}$ & $\begin{array}{c}-0.1862 * * * \\
(0.0012)\end{array}$ \\
\hline 4. Pupuk KCL & $\mathrm{a}_{4}{ }^{* \prime}$ & $\begin{array}{l}-0.0828 \\
(0.0311)\end{array}$ & $\begin{array}{c}-0.0706 * * \\
(0.0026)\end{array}$ & $\begin{array}{c}-0.0575 * * * \\
(0.0107)\end{array}$ \\
\hline 5. Pestisida & $a_{5}{ }^{* \prime}$ & $\begin{array}{c}-0.2177 * * \\
(0.0072)\end{array}$ & $\begin{array}{c}-0.2247 * * \\
(0.0041)\end{array}$ & $\begin{array}{c}-0.2482 * * * \\
(0.0036)\end{array}$ \\
\hline & $\sum \mathrm{a}_{\mathrm{i}}{ }^{*}$ & 0.6961 & 0.5988 & 0.5609 \\
\hline
\end{tabular}

Keterangan : (1). Model I = menggunakan metode pendugaan OLS. Model II = menggunakan metode pendugaan SUR (tanpa restriksi). Model III = menggunakan metode pendugaan SUR (dengan restriksi). (2). Tanda $(*)$ menunjukkan signifikansi pada tingkat kepercayaan $90 \%$ atau $a=10 \%$. Tanda $(* *)$ signifikan pada tingkat kepercayaan $95 \%$ atau $a=5 \%$. Tanda $(* * *)$ signifikan pada tingkat kepercayaan $99 \%$ atau $a=1 \%$. (3). Angka di dalam kurung (.) menunjukkan standard error.

\section{PENGUJIAN KONDISI KEUNTUNGAN YANG MAKSIMUM}

Pengujian hipotesis tentang pencapaian keuntungan maksimum dilakukan untuk mengetahui apakah tingkat penggunaan input variabel pada usahatani kelapa sudah optimum atau belum. Alokasi penggunaan input variabel yang optimum merupakan indikasi bahwa usahatani kelapa telah memberikan keuntungan yang maksimum. Hasil pengujian terhadap hipotesis keuntungan maksimum disajikan pada Tabel 3. 
Tabel 3. Pengujian Hipotesis Keuntungan Maksimum pada Komoditas Kelapa.

\begin{tabular}{clccc}
\hline \multirow{2}{*}{ No } & & \multirow{2}{c}{ Pengujian berdasarkan: } & \multicolumn{2}{c}{ F tabel } \\
\cline { 4 - 5 } & & & 0.01 & 0.05 \\
\hline 1 & Seluruh input secara bersamaan & 98.5523 & 3.02 & 2.21 \\
2 & Tenaga kerja & 12.0897 & 6.63 & 3.84 \\
3 & Pupuk Urea & 5.4558 & 6.63 & 3.84 \\
4 & Pupuk SP36 & 4.9265 & 6.63 & 3.84 \\
5 & Pupuk Kcl & 14.7271 & 6.63 & 3.84 \\
6 & Pestisida & 10.0259 & 6.63 & 3.84 \\
\hline
\end{tabular}

Dari tabel tersebut, terlihat bahwa penggunaan input variabel secara keseluruhan pada komoditas kelapa belum mengindikasikan perilaku penggunaan yang optimum sehingga keuntungan yang dicapai tidak bersifat maksimum. Akan tetapi, secara parsial ada beberapa input variabel yang penggunaannya sudah optimum, yaitu pupuk Urea dan SP-36. Sedangkan tenaga kerja, pupuk KCl dan pestisida, secara parsial penggunaannya masih belum optimum. Secara ekonomi, ini berarti bahwa biaya marjinal dari tenaga kerja, pupuk $\mathrm{KCl}$ dan pestisida belum sama dengan nilai produktivitas marjinalnya atau elastisitas outputnya tidak sama dengan factor share.

\section{PENGUJIAN TERHADAP SKALA USAHATANI}

Skala usaha (return to scale) menggambarkan respon dari luaran atau output terhadap perubahan proporsional dari sejumlah masukan atau input yang digunakan dalam proses produksi. Dalam pengertian praktis, skala usaha ini menunjukkan hubungan antara biaya produksi rata-rata dengan ukuran suatu usaha. Perluasan usaha sampai batas tertentu akan mengakibatkan turunnya biaya produksi rata-rata. Dalam konsepsi ekonomi, keadaan ini disebut dengan skala usaha dengan kenaikan hasil yang bertambah (increasing return to scale). Perluasan selanjutnya akan sampai pada suatu titik atau daerah minimum dimana perluasan usaha tidak akan berpengaruh apa-apa terhadap biaya produksi ratarata. Keadaan ini disebut sebagai skala usaha dengan kenaikan hasil tetap (constant return to scale). Bila titik minimum ini telah dicapai dan perluasan usaha masih terus dilanjutkan, maka perluasan tersebut akan mengakibatkan naiknya biaya produksi rata-rata. Keadaan ini disebut sebagai skala usaha dengan kenaikan hasil yang berkurang (decreasing return to scale).

Untuk usahatani kelapa dengan fungsi keuntungan UOP Cobb Douglass, kondisi skala usaha ini dapat diketahui dengan cara menguji hipotesis apakah $\alpha_{1}+\alpha_{2}+\alpha_{3}$ $+\alpha_{4}=1$ atau $\alpha_{1}+\alpha_{2}+\alpha_{3}+\alpha_{4}>1$ (Lau, 1972; Lopez, 1984). Hasil pengujian hipotesis tentang skala usaha pada usahatani kelapa disajikan pada Tabel 4. 
Tabel 4. Hasil Pengujian Hipotesis Skala Usaha pada Komoditas Kelapa

\begin{tabular}{|c|c|c|c|c|}
\hline Hipotesis & $\begin{array}{c}\text { Nilai } \\
\text { Parameter }\end{array}$ & $\mathrm{F}$ hitung & $\begin{array}{c}\mathrm{F} \text { tabel } \\
0.01 \\
0.05 \\
\end{array}$ & Keputusan \\
\hline $\begin{array}{l}H_{0}: \alpha_{1}+\alpha_{2}+\alpha_{3}+\alpha_{4}=1 \\
H_{a}: \alpha_{1}+\alpha_{2}+\alpha_{3}+\alpha_{4}>1\end{array}$ & 1.7337 & 3.9354 & $\begin{array}{l}2.41 \\
1.88 \\
\end{array}$ & Tolak $\mathrm{H}_{0}$ \\
\hline
\end{tabular}

Dari tersebut dapat dilihat bahwa nilai $\mathrm{F}$ hitung lebih besar bila dibanding dengan $\mathrm{F}$ tabel, baik pada $\mathrm{a}=5 \%$ maupun $\mathrm{a}=1 \%$, sehingga keputusannya adalah tolak $\mathrm{H}_{0}$. Hal ini menunjukkan bahwa kelapa rakyat berada pada fase keuntungan yang semakin meningkat (increasing return to scale). Kondisi ini dapat terjadi karena penggunaan input yang belum optimal sebagaimana umumnya terjadi pada tanaman-tanaman perkebunan yang dikelola dalam bentuk perkebunan rakyat. Contohnya adalah kelapa di daerah Jawa Barat (Sudjarmoko, et al., 1999), kopi di Lampung dan Irian Jaya (Santoso, 1987). Disamping itu, kondisi increasing return to scale juga terjadi karena relatif masih besarnya kontribusi dari input tetap. Keuntungan yang berada pada fase increasing return to scale mengindikasikan bahwa penambahan input masih rasional untuk dilakukan oleh petani kelapa sebab akan menghasilkan tambahan keuntungan yang terus meningkat. Jumlah parameter $\alpha_{j}$ yang lebih besar dari satu menunjukkan bahwa bila penggunaan seluruh input ditambah sebesar satu unit, maka akan menghasilkan keuntungan yang lebih besar dari satu unit. Petani harus berhenti menambah penggunaan seluruh input jika tindakan tersebut akan menghasilkan tambahan yang lebih kecil dari tingkat penambahan input.

\section{KESIMPULAN}

Berdasarkan tujuan penelitian dan analisis yang telah dilakukan, maka dapat disimpulkan bahwa:

1. Keuntungan usahatani kelapa pada perkebunan rakyat dipengaruhi oleh upah tenaga kerja, harga pupuk Urea, SP-36, $\mathrm{KCl}$ dan pestisida. Lima input variabel tersebut memiliki hubungan bersifat negatif dengan tingkat keuntungan. Naiknya upah tenaga kerja, harga pupuk Urea, SP-36, KCl dan pestisida akan menurunkan tingkat keuntungan usahatani kelapa.

2. Input tetap berupa jumlah pohon kelapa, umur pohon kelapa, pendidikan petani dan pengalaman usahatani petani kelapa, juga berpengaruh terhadap keuntungan usahatani kelapa dan memiliki hubungan bersifat positif. Bertambahnya jumlah pohon kelapa, umur pohon kelapa, pendidikan petani dan pengalaman usahatani akan meningkatkan keuntungan usahatani kelapa.

3. Walaupun penggunaan Urea dan SP-36 secara parsial telah optimal, tetapi secara keseluruhan alokasi penggunaan input variabel belum optimal sehingga tidak memberikan keuntungan yang maksimum terhadap usahatani kelapa. 
4. Hasil pendugaan dan pengujian hipotesis tentang skala usaha menunjukkan bahwa usahatani kelapa pada perkebunan rakyat masih berada pada fase keuntungan yang semakin bertambah (increasing returns to scale), sehingga masih dimungkinkan untuk menambah penggunaan input atau perluasan usaha dan perbaikan teknologi.

5. Kelapa perkebunan rakyat yang diusahakan pada ekosistem lahan kering memiliki efisiensi ekonomi, harga dan teknis relatif lebih tinggi dibanding kelapa pada lahan pasang surut. Begitu juga dengan kelapa yang diusahakan pada lahan usahatani luas, tingkat efisiensi ekonomi, harga dan teknis relatif lebih tinggi dibanding kelapa pada yang diusahakan pada lahan usahatani sempit.

\section{IMPLIKASI KEBIJAKAN}

Sesuai dengan kesimpulan yang telah dikemukakan, sejumlah implikasi kebijakan berikut ini kiranya dapat dipertimbangkan untuk pengembangan kelapa nasional:

1. Usaha untuk meningkatkan dan memaksimalkan keuntungan usahatani kelapa pada perkebunan rakyat dapat dilakukan dengan cara meningkatkan penggunaan input berupa tenaga kerja, pupuk $\mathrm{KCl}$ dan pestisida. Hal ini terkait dengan hasil pengujian hipotesis tentang pencapaian keuntungan maksimum yang menunjukkan bahwa penggunaan input variabel secara keseluruhan masih belum optimum, sementara penggunaan pupuk Urea dan SP-36 secara parsial sudah optimum.

2. Usaha untuk meningkatkan dan memaksimumkan keuntungan usahatani kelapa pada perkebunan rakyat juga dapat dilakukan melalui perbaikan teknologi dan perluasan usaha. Hal ini terkait dengan hasil pengujian hipotesis tentang skala usaha yang menunjukkan bahwa usahatani kelapa berada pada fase keuntungan yang bertambah (increasing return to scale).

3. Petani kelapa rata-rata memiliki lahan usahatani yang sempit, sementara kelapa yang diusahakan pada lahan luas memiliki efisiensi yang lebih tinggi. Praktek waris sulit dihindarkan dalam budaya Indonesia, maka fenomena terjadinya fragmentasi lahan, khususnya dalam bentuk alih fungsi lahan menjadi lahan non usahatani harus dapat dicegah oleh pemegang dan pemilik otoritas.

4. Usaha untuk meningkatkan efisiensi ushatani kelapa pada ekosistem lahan pasang surut dapat dilakukan dengan cara memperbaiki kondisi infrastruktur, khususnya yang berkaitan dengan masalah transportasi. Mahalnya transportasi di daerah pasang surut sangat berpengaruh terhadap proses penjualan produk kelapa dan tingginya biaya produksi sehingga akan menurunkan keuntungan dan pendapatan petani kelapa. Memperbaiki infrastruktur tersebut tidak mungkin dapat dilakukan oleh petani tanpa dukungan aktif dari pemerintah daerah dan pusat serta para stakeholder lainnya yang berkepentingan terhadap usaha perkelapaan nasioanal. Usaha untuk meningkatkan efisiensi dan keuntungan usahatani kelapa di wilayah pasang surut ini juga dapat 
dilakukan melalui percepatan proses adopsi teknologi. Berbagai paket teknologi pengelolaan kelapa di lahan pasang surut telah banyak dihasilkan oleh lembaga-lembaga penelitian yang menangani komoditi tersebut. Namun demikian proses adopsi teknologi ini tidak akan berjalan baik bila petani tidak didukung oleh akses yang memadai terhadap lembaga-lembaga penyedia, penyebar dan penyalur teknologi tersebut.

\section{DAFTAR PUSTAKA}

Allorerung, D. 1992. Kendala Pengembangan Kelapa di Lahan Gambut Pasang Surut. Prosiding Forum Komunikasi Ilmiah Penelitian dan Pengembangan Kelapa Pasang Surut. Pusat Penelitian dan Pengembangan Tanaman Industri. Bogor.

dan D. D. Tarigans. 2003. Pengembangan Kawasan Pembangunan Ekonomi Masyarakat Berbasis Agribisnis Kelapa. Prosididng Hari Perkelapaan Keempat Tahun 2002. Bandung, 20 - 22 September 2002. Pusat Penelitian dan Pengembangan Perkebunan. Bogor.

dan Z. Mahmud. 2003. Dukungan Kebijakan Iptek dalam Pemberdayaan Komoditas Kelapa. Prosiding Konferensi Nasional Kelapa V. Tembilahan, 22 - 24 Oktober 2002. Pusat Penelitian dan Pengembangan Perkebunan. Bogor.

APCC. 2005. Coconut Statistical Year Book 2004. Jakarta.

APCC. 2006. Coconut Statistical Year Book 2005. Jakarta.

Direktorat Jenderal Perkebunan. 2001. Establishing a Framework and Selecting Project Sites for a Nation Wide Development of Cococnut Based Poverty Reduction Intervention in Coconut Growing Communities Using COGENT 3 Pronged: Strategy in Indonesia. Implementing Agency: Research Institute for Coconut and Palmae. Balai Penelitian Kelapa dan Palma. Manado.

Badan Pusat Statistik. 2000. Statistik Indonesia Tahun 1999. Biro Pusat Statistik. Jakarta.

Badan Pusat Statistik. 2005. Statistik Indonesia Tahun 2004. Badan Pusat Statistik. Jakarta.

Djaimi. 2001. Dampak Kebijakan Harga Input dan Output Terhadap Penawaran Output dan Permintaan Input Komoditas Karet dan Kelapa Sawit. Tesis Magister Sains. Program Pascasarjana. Institut Pertanian Bogor. Bogor.

FAO. 2005. Production and Trade Year Book. FAO, Roma.

Garcia, P., S.T. Souka, and M.S. Yoo. 1982. Farm Size, Tenure and Economic Efficiency in A Sample of Illinois Grain Farms. American Journal Agricultural Economics. (64) : $119-123$. 
Herman, M., D. Pranowo, H.T. Luntungan, dan H. Tampake. 1998. Pengembangan Kelapa Polikultur di Lahan Pasang Surut. Prosiding Konperensi Nasional Kelapa IV. Bandar Lampung, 21 - 23 April 1998. Pusat Penelitian dan Pengembangan Tanaman Industri. Bogor.

Intriligator,M., R. Bodkin and C. Hsiao. 1996. Econometrics Models, Tecniques, and Applications. Prentice Hall Inc. New Jersey.

Lau, L.J. 1978. Application of Profit Functions. In Fuss and McFadden (eds), Production Economics: A Dual Approach to Theory and Application. North-Holland Publishing Co. Amsterdam.

Lau, L.J. and P.A. Yotopaulus. 1972. Profit, Supply and Factor Demand Function. American Journal of Agricultural Economics. 54(1): 11-18.

Lopez, R.E. 1984. Estimating Substitution and Expansion Effect Using a Profit Function Framework. American Journal of Agricultural Economics. (66): 358 - 357.

Mahmud, Z. 1999. Pengembangan Diversifikasi Usahatani Kelapa Dalam Rangka Peningkatan Pendapatan Petani. Makalah pada Seminar Perkelapaan Indonesia. Coconut Day di Jakarta, 2 September 1999. Pusat Penelitian dan Pengembangan Tanaman Industri. Bogor.

Nair, A.B. 2003. Towards a Successful Coconut Industry Trhough The Strengthening of International Structure: Lesson From The Philippines, India and Sri Lanka Experience. Prosiding Konferensi Nasional Kelapa V. Tembilahan, 22 - 24 Oktober 2002. Pusat Penelitian dan Pengembangan Perkebunan. Bogor.

Saefudin, D. Pranowo, dan D. Listyati. 2002. Penggunaan Dua Model Polatanam Padi dan Kacang Tanah dengan Dasar Kelapa di Kabupaten Sukabumi, Jawa Barat. Jurnal Penelitian Tanaman Industri Volume 8 No. 4. Pusat Penelitian dan Pengembangan Perkebunan. Bogor.

Santoso, B. 1987. Analisis Efisiensi Ekonomi Relatif serta Faktor-faktor yang Mempengaruhi Tingkat Keuntungan pada Usahatani Kopi Rakyat (Studi Kasus pada Beberapa Desa di Lampung). Tesis Magister Sains. Program Pasca Sarjana, Institut Pertanian Bogor. Bogor.

Saragih, B. 1980. Economic Organization, Size and Relatif Efficiency: The Case of Oil Palm Plantations in Notherm Sumatera, Indonesia. PhD. Thesis. North Carolina State University. Raleigh.

Sondakh, L. 1993. Produsen Kelapa dalam Proses Transformasi Struktural Ekonomi Nasional. Prosiding Konferensi Nasional Kelapa III. Yogyakarta, 20-23 Juli 1993. Pusat Peneltian dan Pengembangan Tanaman Industri. Bogor.

Sudjarmoko, B., D. Listyati dan D.D. Tarigans. 1999. Skala Usaha dan Efisiensi Ekonomi Relatif Polatanam Kelapa pada Tingkat Petani di Kabupaten Tasikmalaya, 
Jawa Barat. Jurnal Penelitian Tanaman Industri. Volume IV. No.5: 140 -145. Pusat Penelitian dan Pengembangan Tanaman Industri. Bogor.

Sudjarmoko, B. 2004. Analisis Faktor-faktor yang Mempengaruhi Pendapatan Petani Polatanam Kelapa dengan Pandan. Pusat Penelitian dan Pengembangan Perkebunan. Bogor.

Susila, W.R. 1999. Daya Saing Komoditas Minyak Sawit Indonesia. Jurnal Agribisnis, II (2): 16 -30.

Tarigans, D.D., dan Sumanto. 2002. Penelitian Pola Usahatani Berbasis Kelapa Hibrida di Cimerak. Jurnal Penelitian Tanaman Industri Volume 8 No. 4. . Pusat Penelitian dan Pengembangan Perkebunan. Bogor.

2003. Pengembangan Usahatani Kelapa Berbasis Pendapatan Melalui Penerapan Teknologi Berwawasan Pengurangan Kemiskinan Petani Kelapa di Indonesia. Prosiding Konferensi Nasional Kelapa V. Tembilahan, 22 - 24 Oktober 2002. Pusat Penelitian dan Pengembangan Perkebunan. Bogor.

Warokka, J.S., M.R. Wilson, dan P. Jones. 2003. Skrining Serangga Sebagai Vektor Penyakit Layu Kalimantan pada Tanaman Kelapa. Prosiding Konferensi Nasional Kelapa V. Tembilahan, 22 - 24 Oktober 2002. Pusat Penelitian dan Pengembangan Perkebunan. Bogor. 